\title{
HUBUNGAN TINGKAT PENGETAHUAN DAN SIKAP MASYARAKAT TERHADAP KEBIASAAN BABS DILINGKUNGAN BAURUNG KELURAHAN BAURUNG KECAMATAN BANGGAE KABUPATEN MAJENE
}

\author{
Haerani $^{1)}$ \\ ${ }^{1)}$ Prodi Diploma Kebidanan STIKes Bina Bangsa, Majene, Sulawesi Barat \\ E-mail: haerani.sst90@gmail.com
}

\begin{abstract}
ABSTRAK.
Kebiasaan BABS adalah suatu tindakan membuang kotoran atau tinja di ladang, hutan, semak-semak, sungai, pantai atau area terbuka lainnya dan dibiarkan menyebar mengkontaminasi lingkungan, tanah, udara dan air. Rumusan masalah yaitu apakah ada hubungan tingkat pengetahuan dan sikap masyarakat terhadap kebiasaan BABS di Lingkungan Baurung. Tujuan penelitian ini untuk mengetahui apakah ada hubungan pengetahuan dan sikap masyarakat terhadap kebiasaan BABS di Lingkungan Baurung. Metode penelitian yang digunakan adalah survey analytic denganpendekatan Cross Sectional. Populasi penelitian adalah semua KK yang bertempat tinggal di Lingkungan Baurung. Sampel penelitian sebanyak 107 responden dengan menggunakan Simple Random Sampling. Teknik analisa data menggunakan ujiChi Square untuk mengetahui hubungan pengetahuan dan sikap masyarakat terhadap kebiasaan BABS di Lingkungan Baurung. Hasil analisa univariat dan bivariat menunjukkan distribusi responden berdasarkan umur, jenis kelamin, pekerjaan, pendidikan, kebiasaan BABS, tingkat pengetahuandan sikap masyarakat.Hasil analisa berdasarkan pengetahuan, pengetahuan dengan tingkatan cukup lebih banyak di banding pengetahuan dengan tingkatan kurang dengan hasil uji chi square $\mathrm{p}=0,132>0,05$ sehingga dapat disimpulkan bahwa tidak ada hubungan pengetahuan terhadap kebiasaan BABS atau Ho diterima, dan analisa berdasarkan sikap $\mathrm{p}=0,003<0,05$ menunjukkan bahwa ada hubungan sikap terhadap kebiasaan BABS atau Ho ditolak. Disarankan kepada masyarakat dapat berperilaku sesuai sikap agar tidak ada lagi masyarakat yang BAB sembarangan.
\end{abstract}

Kata kunci: Kebiasaan BABS, Pengetahuan, dan Sikap.

\section{PENDAHULUAN}

BABS merupakan suatu tindakan membuang kotoran atau tinja di ladang, hutan, semak-semak, sungai, pantai atau area terbuka lainnya dan dibiarkan menyebar mengkontaminasi lingkungan, tanah, udara dan air (Mukherjee, 2011). Sanitasi, personal higiene dan lingkungan yang buruk berkaitan dengan penularan beberapa penyakit infeksi yaitu penyakit diare, kolera, typhoid fever dan paratyphoid fever, disentri, penyakit cacing tambang, ascariasis, hepatitis A dan E, penyakit kulit, trakhoma, schistosomiasis, cryptosporidiosis, malnutrisi dan penyakit yang berhubungan dengan malnutrisi (Cairncross, 2013). Prevalensi penyakit akibat sanitasi buruk di Indonesia adalah penyakit diare sebesar $72 \%$, cacingan $0,85 \%$, scabies $23 \%$, trakhoma $0,14 \%$, hepatitis A $0,57 \%$, 
hepatitis E 0,02\% dan malnutrisi 2,5\%, sedangkan kasus kematian akibat sanitasi buruk adalah diare sebesar $46 \%$, cacingan $0,1 \%$, scabies $1,1 \%$, hepatitis A $1,4 \%$ dan hepatitis E 0,04\% (WSP-EAP, 2008).

Tinja merupakan bahan buangan yang dikeluarkan dari tubuh manusia melalui anus sebagai sisa dari proses pencernaan makanan di sepanjang sistem saluran pencernaan (tractus digestifus). Pengertian tinja ini juga mencakup seluruh bahan buangan yang dikeluarkan dari tubuh manusia termasuk karbon monoksida $(\mathrm{CO} 2)$ yang dikeluarkan sebagai sisa dari proses pernafasan, keringat, lendir dari ekskresi kelenjar, dan sebagainya (Soeparman, 2002:11). Ekskreta manusia (human excreta) yang berupa feses dan air seni (urine) merupakan hasil akhir dari proses yang berlangsung dalam tubuh manusia yang menyebabkan pemisahan dan pembuangan zat-zat yang tidak dibutuhkan oleh tubuh (Chandra, 2007:124).

Berdasarkan data WHO pada tahun 2010 diperkirakan sebesar 1,1 milyar orang atau $17 \%$ penduduk dunia masih $\mathrm{BABs}$, dari data tersebut diatas sebesar $81 \%$ penduduk yang BABs terdapat di 10 negara dan Indonesia sebagai Negara kedua terbanyak ditemukan masyarakat BABs, yaitu India (58\%), Indonesia (5\%), Ethiopia (4,4\%), Pakistan (4,3\%), Nigeria (3\%), Sudan $(1,5 \%)$, Nepal $(1,3 \%)$, dan Niger $(1,1 \%)$ (WHO, 2011). Di Indonesia, penduduk yang masih BABs sebesar 5\% merefleksikan $26 \%$ total penduduk Indonesia. Hasil Riskesdas 2010 menunjukkan penduduk yang BABs sebesar 36,4\% Sedangkan akses sanitasi dasar sebesar 55,5\% (Balitbangkes, 2010). Di Propinsi Jawa Tengah masih ditemukan penduduk yang BABs sebesar $33,4 \%$, data sanitasi dasar kepemilikan jamban sebesar
71\% (2008), 72\% (2009) dan 65\% (2010), akses air bersih 74\% (2008), 78\% (2009) dan 77\% (2010), sedangkan Angka kesakitan diare terjadi peningkatan yaitu 1,86\% (2008) dan 1,95\% (2009) (Dinkes Jateng, 2010).

Perilaku merupakan aktivitas seseorang yang merupakan bentuk respons terhadap suatu stimulus dari luar, dan berbeda beda tiap respons yang diberikan tergantung pada faktor faktor darin orang yang bersangkutan, baik faktor internal ataupun eksternal.Pengetahuan merupakan hasil dari tahu setelah terjadi pengindraan terhadap suatu objek tertentu. Sebagian besar pengindraan manusia diperoleh melalui mata dan telinga. Sikap merupakan reaksi atau respon seseorang yang masih tertutup terhadap suatu stimulus atau Obyek Psikologi (Soekidjo N, 2003). Obyek psikologi di sini meliputi : simbol, kata-kata, slogan, orang, lembaga, ide dan sebagainya. Newcomb dalam Notoatmodjo (2003) menyatakan bahwa sikap merupakan kesiapan atau kesediaan untuk bertindak, dan bukan merupakan pelaksanan motif tertentu. Sikap belum merupakan suatu tindakan atau aktifitas, akan tetapi adalah merupakan pre-disposisi tindakan atau perilaku.

\section{RANCANGAN PENELITIAN}

Jenis penelitian yang digunakan dalam penelitian ini adalah Penelitian ini merupakan penelitian kuantitatif dengan menggunakan metode survey analitik dengan pendekatan cross sectional

Populasi dalam penelitian ini adalah Populasi yang digunakan dalam penelitian ini adalah semua KK yang bertempat tinggal di lingkungan Baurung kelurahan Baurung Kecamatan Banggae Timur Kabupaten Majene yang berjumlah 147 
KK.Sampel pada penelitian adalah sebagian jumlah KK yang mewakili seluruh populasi yaitu $107 \mathrm{kk}$.

\section{PEMBAHASAN}

1. Hubungan tingkat pengetahuan terhadap kebiasaan BABS

Dari hasil penelitian dapat diketahui bahwa pengetahuan masyarakat terhadap kebiasaan BABS dengan tingkat pengetahuan cukup mencapai $57,9 \%$ dari semua jumlah responden yang ditentukan peneliti sedangkan jumlah responden yang memiliki pengetahuan kurang mencapai $42,1 \%$ pada tingkatan ini masyarakat yang mempunyai pengetahuan kurang tentang kebiasaan BABS disebabkan karena kurangnya informasi yang mereka dapatkan, kurangnya penyuluhan tentang dampak dari kebiasaan perilaku tidak sehat tersebut, selain itu kebanyakan masyarakat yang berpendidikan rendahlah yang memiliki pengetahuan kurang dan adapun yang beranggapan bahwa BAB di laut tidak berdampak apapun karena terbawa arus katanya sehingga meskipun ada penyuluhan dari pemerintah setempat mereka merasa tidak penting untuk mengikutinya dan ada sebagian masyarakat yang sudah memiliki jamban tapi masih BAB di laut karena perilaku tidak sehat tersebut sudah menjadi kebiasaan mereka sejak dulu dan menurut mereka laut merupakan salah satu tempat $\mathrm{BAB}$ yang praktis.

Dari hasil uji chi square responden yang memiliki pengetahuan cukup yang $\mathrm{BAB}$ di WC sebanyak 28 responden atau $45,2 \%$, dan responden yang memiliki pengetahuan cukup yang BAB tidak di WC sebanyak 34 responden atau 54,8\%. Sedangkan responden yang memiliki pengetahun yang kurang yang BAB di WC sebanyak 13 responden $28,9 \%$ dan yang berpengetahuan kurang yang $\mathrm{BAB}$ tidak di WC sebanyak 32 responden atau $71,1 \%$. Ini menandakan bahwa responden yang memiliki pengetahuan cukup tidak semua melakukan perilaku $\mathrm{BAB}$ yang baik dan benar, terbukti bahwa beberapa dari responden yang memiliki pengetahuan cukup masih $\mathrm{BAB}$ di tempat terbuka atau tidak BAB di WC.

Hal ini tidak sesuai dengan teori yang dikemukakan oleh Notoatmodjo (2010), yang menyatakan bahwa seseorang melakukan perilaku atau tindakan disebabkan karena adanya pengetahuan dan sikap yang dimilikinya. Pengetahuan atau kognitif merupakan domain yang sangat penting untuk terbentuknya praktek atau tindakan seseorang. Salah satu unsur yang diperlukan agar dapat berbuat sesuatu adalah pengetahuan dan jika kita menghendaki sesuatu dapat dikerjakan dengan terus menerus maka diperlukan pengetahuan yang positif tentang apa yang harus dikerjakan, dengan kata lain perilaku atau tindakan yang dilandasi pengetahuan akan lebih langgeng dibanding praktek atau tindakan yang tanpa didasari pengetahuan dan tingkat pengetahuan seseorang mempengaruhi praktek individu, semakin tinggi pengetahuan seseorang semakin tinggi kesadaran untuk berperan serta.

Dalam kuesioner yang peneliti bagikan kepada responden terdapat beberapa pertanyaan mengenai pengetahuan tentang BABS, jamban, bahaya BABS, penyakit yang dapat ditularkan tinja, cara pemutusan rantai penularan penyakit dari tinja dan lain sebagainya. Dari jawaban yang responden berikan, menjelaskan fakta bahwa masih banyak masyarakat yang minim pengetahuan tentang BABS, jamban, bahaya BABS, penyakit yang dapat ditularkan tinja, cara pemutusan 
rantai penularan penyakit dari tinja serta pentingnya memiliki jamban keluarga.

Hal ini dikarenakan masyarakat yang berpengetahuan cukup belum tentu melakukan suatu tindakan sesuai dengan pengetahuan yang mereka miliki, misalnya masyarakat sudah mengetahui manfaat jamban, bahaya BABS, penyakit yang ditularkan tinja, dan lain sebagainya tapi masih banyak yang BAB sembarangan dan masih banyak yang tidak memiliki jamban keluarga.

2. Hubungan sikap masyarakat terhadap kebiasaan BABS

Dari hasil penelitian dapat diketahui, bahwa sikap masyarakat terhadap kebiasaan BABS dengan sikap yang negatif mencapai $41,1 \%$ dari semua jumlah responden yang ditentukan peneliti sedangkan jumlah responden yang memiliki sikap yang positif mencapai $58,9 \%$. Pada tingkatan ini masyarakat yang mempunyai sikap positif lebih banyak dibanding sikap negatif, ini menandakan bahwa pengetahuan yang masyarakat miliki berbanding terbalik dengan sikap masyarakat, dan fakta dilapangan memang menunjukkan bahwa masih banyak masyarakat yang $\mathrm{BAB}$ sembarangan.

Hal ini dikarenakan banyak masyarakat yang bersikap positif dari pada yang bersikap negatif, namun fakta menunjukkan sikap positif yang masyarakat miliki tidak direalisasikan. Jika semakin banyak masyarakat yang bersikap positif maka semakin banyak pula mereka melakukan suatu tindakan, sebaliknya semakin besar masyarakat yang bersikap negatif maka semakin besar pula mereka tidak melakukan suatu tindakan. Jadi dalam penelitian ini terdapat hubungan antara sikap masyarakat terhadap kebiasaan BABS.

Dalam penelitian ini terkait masyarakat yang mempunyai sikap positif maupun negatif dibedakan menjadi 2 kategori kebiasaan BABS yakni kebiasaan BAB di WC dan kebiasaan BAB tidak di WC. Dari tabel analisis menunjukkan banyak masyarakat yang bersikap positif yang $\mathrm{BAB}$ di WC dibanding masyarakat yang BAB tidak di WC tetapi hanya terpaut satu responden, hal ini berarti masih banyak masyarakat yang bersikap positif tapi masih BAB sembarangan, sedangkan masyarakat yang bersikap negatif yang BAB di WC lebih rendah dibanding responden yang $\mathrm{BAB}$ tidak di $\mathrm{WC}$ sesuai jawaban yang responden berikan terkait kuesioner penelitian.

Dari hasil uji chi squre responden yang memiliki sikap negatif yang BAB di WC sebanyak 9 responden atau 20,5\% dan responden yang memiliki sikap negatif yang BAB tidak di WC sebanyak 35 responden atau $79,5 \%$, sedangkan responden yang memiliki sikap positif yang $\mathrm{BAB}$ di $\mathrm{WC}$ sebanyak 32 responden atau $50,8 \%$ dan responden yang memliki sikap positif yang BAB tidak di WC sebanyak 31 responden atau $49,2 \%$. Ini menandakan bahwa responden yang memiliki sikap positif berpengaruh terhadap kebiasaan BABS.

\section{KESIMPILAN DAN SARAN}

Kesimpulan penelitian Tidak ada hubungan antara pengetahuan responden terhadap kebiasaan BABS di Lingkungan Baurung Kecamatan Banggae Timur Kabupaten Majene . Ada hubungan antara sikap responden terhadap kebiasaan BABS di 
Lingkungan Baurung Kecamatan Banggae Timur Kabupaten Majene

Saran dalam penelitian ini adalah Diharapkan masyarakat dapat melakukan tindakan sesuai sikap, dari hasil penelitian diperoleh banyak masyarakat yang memiliki sikap positif meskipun dengan pengetahuan minim, sehingga lingkungan bisa tetap terjaga dan bersih dari perilaku $\mathrm{BAB}$ sembarangan.

\section{DAFTAR PUSTAKA}

Anita, 2016.skripsi.Hubungan Tingkat Pengetahuan dan Sikap Pedagang Terhadap Pengelolaan Sampah di Pasar Tradisional Tinambung .Skripsi.Tidak Diterbitkan .Majene: Sekolah Tinggi Ilmu Kesehatan Bina Bangsa Majene.

Dwiana, A.2016. Determinan Perilaku Buang Air Besar Pada Masyarakat Pesisir Di Kabupaten Buton Selatan (online).

https://media.neliti.com/media /publications/237880-faktorfaktor-yang-berhubungandengan-pe-f93532dc.pdf di akses pada tanggal 11 Agustus 2018.

Farah, A.2014. Perilaku BAB di Sungai Pada Warga Kelurahan Sekayu Semarang.(online) https://eprints.dinus.ac.id/6688 /1/jurnal_13839.pdf di akses pada tanggal 19 Agustus 2018.
Febriani, W.2016.Faktor Yang Mempengaruhi Perubahan Perilaku Stop Buang Air Besar Sembarangan (Babs): Studi Pada Program Stbm Di Desa Sumbersari Metro Selatan. (online). https://www.researchgate.net/ publication/317064995 di akses pada tanggal 19 Agustus 2018.

Harum, Akhmad. 2012. Makalah sikap (online) https://bukunnq.wordpress.co m/2012/03/06/makalah-sikap/ di akses pada tanggal 5 juli 2018.

Keputusan Menteri Kesehatan RI Nomor 852 /Menkes /SK /IX 12008.Sanitasi Total Berbasis Masyarakat.

Kurniawati, Linda Destiya.2015. Faktor - Faktor Yang Berpengaruh Terhadap Perilaku Kepala Keluarga Dalam Pemanfaatan Jamban Di Pemukiman Kampung Nelayan Tambak Lorok Semarang.(online) http://lib.unnes.ac.id/23499/1/ 6411411207.pdf di akses pada tanggal 19 Agustus 2018.

Mufidah, Inganatul.2017.pengaruh program STBM dengan pemberian stiker $O D F$ (online)http://repository.ump.a c.id/4654/2/INGANATUL\%2 0MUFIDAH\%20BAB\%20I.p 
df Diakses pada tanggal 28 Mei 2018.

Notoatmodjo, S. 2011.kesehatan masyarakat: ilmu dan seni.Edisi revisi. Jakarta : PT RinekaCipta.

Otaya, Lian G.2011.Pengetahuan, Sikap dan Tindakan Terhadap Penggunaan Jamban Keluarga. (online)

.https://download.portalgaruda. org/article.php? article $=41466 \&$ val=3594 di akses pada tanggal 19 Agustus 2018.

Sari, Alviana Nurfita.2016.Hubungan Tingkat Pengetahuan, Sikap Dan Pendapatan Dengan Perilaku Buang Air Besar Keluarga Di Desa Kerjokidul Kecamatan Ngadirojo Kabupaten Wonogiri(online) http://eprints.ums.ac.id/48101/3/03 $\% 20$ HALAMAN\%20JUDUL.pdf di akses pada tanggal 19 Agustus 2018 .

Sukardi, 2010.Masalah penyehatan lingkungan pemukiman khususnya pada pembuangan tinja

Triyono, Agus.2014.Faktor-Faktor Yang Berhubungan Dengan Perilaku Buang Air Besar Masyarakat Nelayan Di Kampung Garapan Desa Tanjung Pasir Kabupaten Tangerang Propinsi Banten.(online)http://download.por talgaruda.org/article.php?article $=3$ $14524 \& \mathrm{val}=5028 \&$ title FaktorFaktor yang Berhubungan dengan Perilaku Buang Air Besar
Masyarakat Nelayan di Kampung Garapan Desa Tanjung Pasir Kabupaten Tangerang Propinsi Banten diakses pada tanggal 02 juni 2018.

Tim Dosen Stikes BBM.2018. Panduan Penyusunan Skripsi, Program Studi Kesehatan Masyarakat, Majene: Prodi Kesmas Stikes BBM.

Wahab Abdul,2012. Pengantar Riset (Bidang Kesehatan Kebidanan dan Keperawatan).Edisi Pertama, Yogyakarta :Kutub Wacana

Wahyuningsih,Nur Endah.dkk.2016. Pengaruh Metode Pemicuan Terhadap Perubahan Perilaku Buang Air Besar Sembarangan Pada Masyarakat Kelurahan Kauman Kidul Kota Salatiga (online)

https://media.neliti.com/media/pub lications/108759-ID-pengaruhmetode-pemicuan-terhadapperuba.pdf di akses pada tanggal 25 Mei 2018. 